Diabetes

\section{An unusual cause of pleural effusion}

\section{A Reghukumar, V Chandran, J M Pappachan, J Antony, K Vijayakumar}

\section{Answers on $p$ el9}

A 72 year old man with 30 years history of type 2 diabetes mellitus who had been taking insulin for the previous 12 years was brought to the emergency department with breathlessness and lethargy of two days duration. He had diarrhoea and abdominal pain for three weeks and productive cough for one week and had omitted insulin for one week because of tiredness.

On admission he was afebrile with a pulse rate of 120 beats/min, respiratory rate $30 / \mathrm{min}$, blood pressure $90 / 70 \mathrm{~mm}$ $\mathrm{Hg}$ and was clinically dehydrated. Minimental score was $7 / 10$. Chest examination and a radiograph showed a pleural effusion on the left side. There was no other abnormality on physical examination.

His plasma glucose was $16.5 \mathrm{mmol} / \mathrm{l}$ and urine ketostix reaction was +++ . Arterial blood gas analysis showed: partial pressures of oxygen and carbon dioxide $11 \mathrm{kPa}$ and $3.6 \mathrm{kPa}$ respectively while breathing room air; $\mathrm{pH} 7.2$ and bicarbonate $12 \mathrm{mmol} / \mathrm{l}$. Biochemical investigations showed: urea $10.6 \mathrm{mmol} / \mathrm{l}$; creatinine $\quad 130 \mu \mathrm{mol} / \mathrm{l}$; sodium $\quad 129 \mathrm{mmol} / \mathrm{l} ; \quad$ potassium $5.3 \mathrm{mmol} / \mathrm{l}$; chloride $104 \mathrm{mmol} / \mathrm{l}$, and corrected calcium $2.3 \mathrm{mmol} / \mathrm{l}$. Liver functions and toxicology screen were normal. His erythrocyte sedimentation rate was $92 \mathrm{~mm}$ in the first hour. The haemoglobin, total and differential white cell counts, platelet count, and mean corpuscular volume were normal.

The electrocardiograph showed sinus tachycardia without evidence of ischaemia and the echocardiogram was normal.

The pleural fluid was turbid with a white cell count of $7.8 \times 10^{9} / 1$, neutrophil count $6.9 \times 10^{9} / 1$, and lymphocyte count $0.9 \times 10^{9} /$. The $\mathrm{pH}$ was 7.2 . The Gram stained smear showed the parasite in the picture (fig 1A). Similar parasites were seen in the sputum (fig 1B) and stool smears (fig lC).

$\mathrm{He}$ died eight hours later after a generalised tonic-clonic seizure while being treated in the intensive care unit.

His remaining laboratory reports were obtained later. Peripheral blood smear did not show any abnormal cells and the serology was negative for HIV, HTLVI, hepatitis B, and C antibodies. The blood culture had grown Citrobactor koseri and the sputum and pleural fluid cultures had grown Klebsiella pneumoniae.

\section{QUESTIONS}

1. What is the clinical diagnosis?

2. What is the parasite?

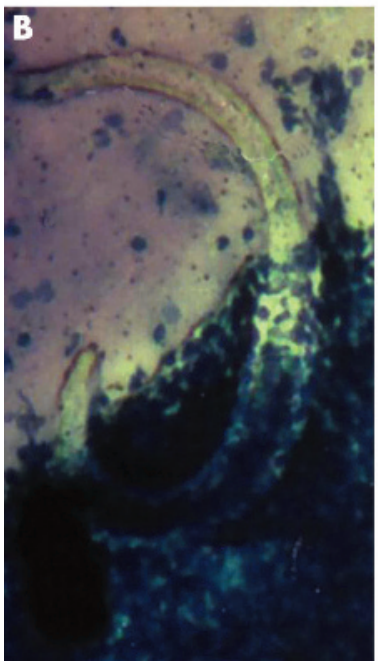

3. What are the conditions predisposing to this kind of presentation?

Postgrad Med J 2006:82:e17 http://www.postgradmedi.com/cgi/content/ ull/82/969/el7)

doi: $10.1136 /$ pgmi.2006.045948

\section{Authors' affiliations}

A Reghukumar, V Chandran, J M Pappachan, J Antony, K Vijayakumar, Department of Medicine, Kottayam Medical College, South India

Correspondence to: Dr M J Pappachan Department of Medicine, Kottayam Medical College, South India 686008; drpappachan@ yahoo.co.in

Submitted 29 January 2006

Accepted 21 February 2006

Funding: none.

Competing interests: none.
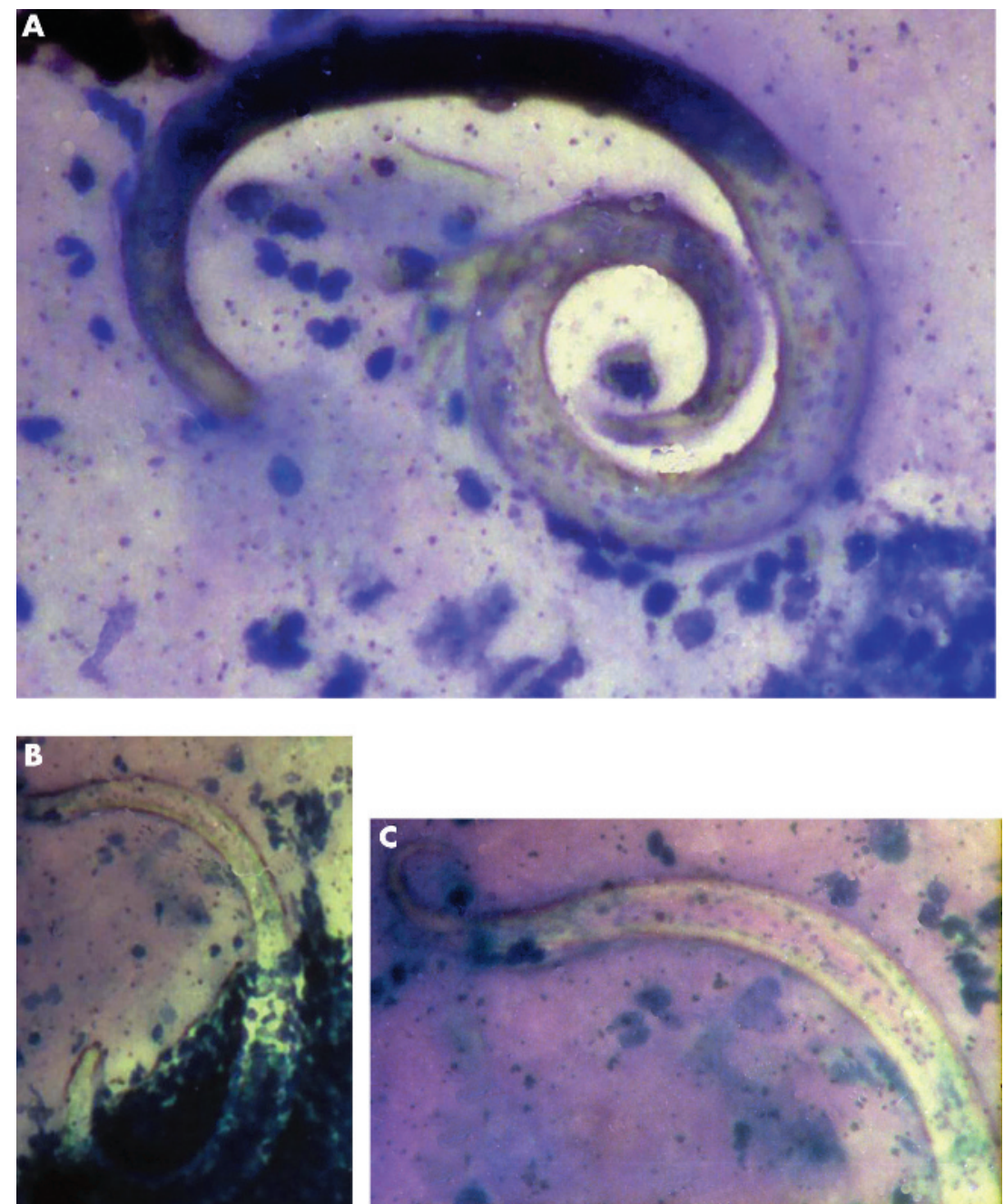

Figure 1 Parasite seen in (A) Gram stained smear; (B) sputum smear; (C) stool smear. 